\title{
7. 'Crime to be a Woman?': Engendering Violence against Female Sex Workers in Port Moresby, Papua New Guinea
}

\author{
Christine Stewart
}

\section{Abstract}

In 2004, police raided an alleged brothel in Port Moresby, capital of Papua New Guinea, and amidst general mayhem, rounded up all present, men, women and children, and marched them to the police station where nearly forty women and girls were charged with prostitution. A newspaper report of the incident claimed that male sex workers were freed because there was no legal provision enabling their arrest. This elicited a swift response from the National AIDS Council lawyer, to the effect that this was an unfair denial of the constitutional right to equality before the law regardless of sex, and that male sex workers should have been charged as well.

This chapter asks whether, in the face of evidence that men were also abused, the violence was gendered and if so, how and why. This requires examination of the development of the gendered view of the prostitute, the continuance of the view that wayward women should be punished by violence of a sexual nature, and the transference of concepts of pollution into the sphere of social panic about the burgeoning HIV epidemic in the country.

\section{The raid}

In March 2004, early on a Friday afternoon, police raided the Three-Mile Guesthouse in the Boroko suburb of Port Moresby, the capital of Papua New Guinea (PNG). ${ }^{1}$ The guesthouse, a converted colonial residence, is typical of the many premises which provide short- and long-term accommodation at the lower end of the socio-economic scale-rooms are also let to women who sell

1 This account is compiled from newspaper reports, verified statements taken from many of those caught up in the raid and other documents and reports concerning the raid, all of which I have collected as part of my PhD fieldwork from 2004 to 2007. 
sex and collect their own payment. Facilities include a bar, a snooker table and gaming machines. Some women peddle cooked food, cigarettes and betel nut in the front yard or outside the gate. It is open by day as well as in the evening, which allows housewives to visit and augment their domestic finances without their families knowing.

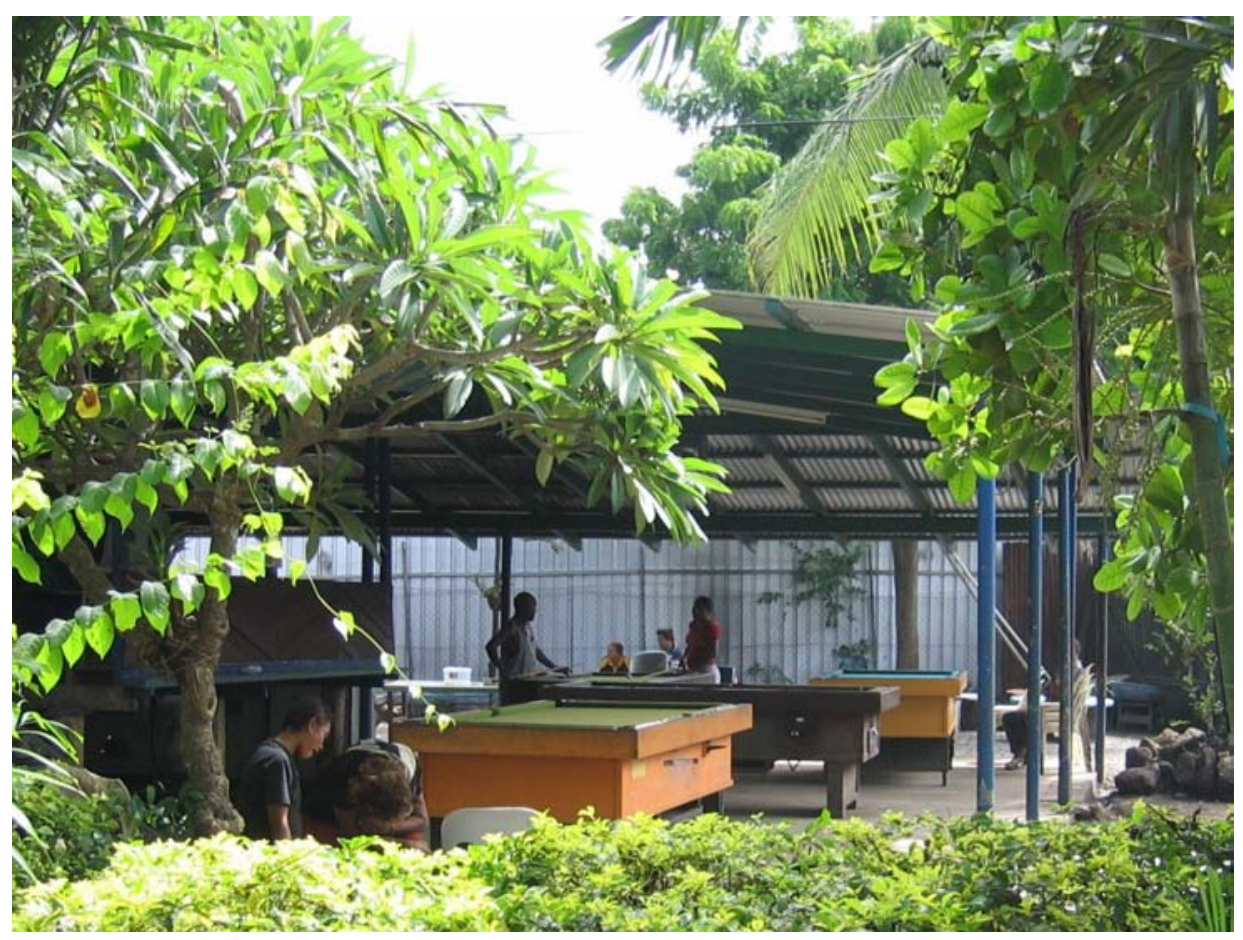

\section{Figure 8. Typical club, Port Moresby, 25 January 2006.}

Photograph by Christine Stewart.

The police raid was accompanied by extreme violence. People were beaten with everything from pool cues to rifle butts - some women were sexually assaulted. One twenty-three-year-old reported that police forced her into a room at gunpoint, beat her with rubber hoses, told her to take off her jeans and underwear, forced an air freshener canister and then a beer bottle into her vagina and then ordered her to perform oral sex on them. Food was dumped over the vendors, beer over the drinkers. Police seized alcohol and the till takings, gaming machines, snooker tables and kitchen appliances. They snatched people from the rooms, rifled through bags and helped themselves to money and valuables. They confiscated condoms from the rooms and, by continual threats and beatings, forced the women to chew and swallow them. Then all those present - men, women and even children-were lined up and marched at gunpoint a mile or more through the streets to the police station. 
The grim procession was headed by a police truck loaded with the goods looted from the premises. The women were forced to hold condoms in their mouths or wave them like balloons above their heads as they marched. A crowd gathered quickly to jeer at the unfortunates, spit on them, pelt them with stones and bottles and taunt them for selling sex and spreading disease.

At the police station, reporters from the local television station and the daily newspapers were waiting, presumably tipped off by the police. ${ }^{2}$ More than forty men caught up in the raid were released, but the women were seated on the grass outside the station, and processed in batches. While they were waiting, the Metropolitan Police Superintendent addressed them. He told them that the raid had been conducted to prevent sex workers from contracting and spreading HIV.

Some thirty-nine women and girls were charged for 'living on the earnings of prostitution', which is the charge under the Summary Offences Act 1977 used in PNG for acts of prostitution. For a day and a half, they were held in hot crowded cells at the station, without food, washing facilities or medical attention for their injuries. Supporters from the National AIDS Council, NGOs and community organisations brought food and comfort. Some NGO workers managed to gain access to the station and stayed with the women in the stinking cells. That night, four young women were taken out and offered a lift home but, once in the police vehicle, were told they had to provide sex first. Two agreed, but two refused and were returned to the lockup. After two nights in the cells, the women were finally released in the early hours of Sunday morning. Legal assistance was provided by AusAID's HIV support program, ${ }^{3}$ and some three weeks later, upon discovery that no search warrant had been issued in respect of the raid, the charges were dropped. A court claim for compensation for abuse of human rights was filed but has not been pursued, reportedly on the grounds that the individual policemen involved could not be identified (Human Rights Watch 2005: 116; see also Ombudsman Commission of Papua New Guinea 2009).

The Monday after the raid, both PNG English-language daily newspapers, the National and the Post-Courier, ran the story. The Post-Courier's front-page report 'Sex workers on parade' included a paragraph stating that:

[a]mong those arrested - including both male and female prostituteswas a 13-year-old girl (Yiprukaman 2004a: 87-88).

The Post-Courier also ran an editorial, which commenced by castigating the police for mounting such a

2 Michael Goddard mentions this tip-off process in relation to other types of raids (Goddard 2005: 20-21).

3 AusAID, the Australian government's overseas aid program, established its first HIV-specific support program in late 2000 . 
public humiliation ritual... [t]hat's an interesting experiment in social reform or pre-trial processing. The defence lawyers will find it valuable in mounting a case against the prosecution. Certainly it must have been good entertainment for the street folk (Editorial 2004a).

The editor then proceeded to praise the Superintendent for his wise words of warning to the detainees:

The police commander who assembled the charged people on the lawn outside the police station and warned them of the perils of their socalled profession was doing the right thing (Editorial 2004a).

'But will they listen?' The editor went on:

The only trouble is in getting those people to take note of it after they are dealt with by the courts. Looking to the future is not a thing that prostitutes are noted for. They are often on the bottom rung of society's ladder and have few social or working skills to be able to climb higher in society.

Usually, their prime task is to find money to feed and house themselves and the knowledge that they can satisfy those needs by selling their bodies comes before the 'finer things of life'.

Will any of those charged people get off the bottom rung or will they be inevitable dregs of the hospital wards soon and among those anonymous carcasses to be bulldozed into a mass burial pit at Bomana cemetery one day soon, victims of HIV/AIDS? (Editorial 2004a).

The National's report included a photo and a small story, relating how the Superintendent had lamented the increase in prostitution:

It was a sad thing to see girls, as young as 14,15 and 16 years of age sitting among the group ... some of these young girls' clients were men as old as 60 ... times were tough and prostitution among young women was increasing.... [they] were risking their lives and could easily catch AIDS ... the women are drunk in most cases and do not take safety precautions like using condoms ... prostitution was the main cause of HIV/AIDS virus spreading like bushfire (Pilimbo 2004: 5).

The following day, Tuesday 16 March, the Post-Courier produced another frontpage headline: 'Males "freed" ... but 31 suspected female prostitutes charged!'

FORTY-FIVE men rounded up by police for alleged prostitution walked free yesterday because there are no provisions in the law to charge male sex workers. 
However, 31 women were arrested and charged because Section 55 of the Summary Offences Act of the Criminal Code [sic] provides for female sex workers to be charged.

However, a senior government lawyer yesterday said sections 55 and 57 of the law were not designed to single out women prostitutes.

The lawyer said the charging of people was the discretion of the police depending on the kind of information at hand.

It was not right to say that the provisions did not cater for charges being filed against male prostitutes.

A prostitute is someone who earns a living from sexual favours or earns a living by providing the venue for prostitution.

National AIDS Council lawyer Bomal Gonapa ... said outside court that 35 men were released from police custody because there was no provision under the current Summary Offences Act of the Criminal Code Act that covered male prostitutes.

'The release of the male suspects was not fair to their female counterparts because they were all engaged in such an activity,' Mr Gonapa said. (Yiprukaman 2004b).

Raids such as the Three-Mile Guesthouse Raid are a common policing strategy in PNG towns, usually conducted in urban settlements in a search for stolen goods and suspected criminals (Dinnen 2001: 64; Goddard 2001: 3-4). Accompanying violence, including sexual violence, is commonplace, and derives partly from a perception on the part of the police and the community in general that the imported model of criminal justice is failing, and partly from a policing tradition based on early frontier-pacification strategies (Dinnen 1998a: 260-61; Dinnen 1998b: 360; Jenkins 2000: 22).

Raids have been conducted before at the Three-Mile Guesthouse, which is owned by a controversial former politician and diplomat (Nicholas 1996; Konia 1998; Sela 1998; Terry 1998). The brutality evidenced in these raids seems to be increasing. In a raid in 1996, reportedly the biggest to date (Nicholas 1996), the women were trucked to the police station: in 1998, when police claimed that 'the problem was worsening' (Terry 1998), the women were force-marched. Police harassment of those selling sex throughout the city appears to have increased steadily, until this 2004 raid which was clearly such an abuse of human rights that it elicited strong public comment and condemnation.

Unlike these previous raids, which rated only brief news reports, the 2004 raid provoked a number of comments and a good deal of reportage, both locally 
and internationally. The two PNG English-language newspaper reports of the incident and its aftermath were widely available as hard-copy and online, and included one or two letters to the editor commenting on the incident. Briefs were written shortly after the incident by the government's body the National AIDS Council Secretariat (National AIDS Council Secretariat 2004) and by the Project Manager of the Poro Sapot Project (PSP), an initiative of the international NGO Save the Children which provides awareness, condoms and clinical support for marginalised groups in various locations in PNG, including Boroko (Hershey 2004; Reid 2010). Both these briefs provided information for the narrative account above. The entire incident was documented later that year by the international NGO Human Rights Watch, which based its account on statements made by women and girls involved in the raid, and on its own interviews conducted in September 2004 (Human Rights Watch 2005: 118-21). The incident also provoked comment and discussion on two email-lists, AIDSTOK (hosted by the Secretariat of the Pacific Community for discussion on HIV and other sexually transmitted infections (STIs) in the Pacific) and ASAONET (serving anthropologists around the world working in Oceania). The coordinator of the Global Network of Sex Work Projects (NSWP), an international organisation for promoting sex workers' health and human rights, wrote to all PNG Embassies and High Commissions world-wide, protesting the violence.

A few days after the women were released the National Capital District (NCD) Provincial AIDS Committee ${ }^{4}$ convened a meeting of government representatives, NGOs and churches. Among other things, a court claim for damages for breach of human rights was proposed, and written statements were taken by and from many of those involved. The statements taken reflected the need to emphasise the injuries, both physical and psychological, that were visited on them. The women were continually advised not to mention receiving money for sex, but one or two did.

All these accounts and ongoing discussions illustrate the interests of their makers and commentators, and exemplify the discourses operating in PNG today which surround the selling of sex, its gendering, its condemnation and the violence associated with it. The Post-Courier editorial of 15 March declared that:

PROSTITUTION has been a whipping boy of politicians, social interest groups and police ever since the 'profession' was first encountered (Editorial 2004a).

Is this in fact the case? Is there a 'profession' in PNG? Has it been a 'whippingboy' and if so why? This paper examines the Three-Mile Guesthouse Raid through the lens of several of these reports, comments and statements, all of

4 The National AIDS Council established these committees for each province and the National Capital District. 
which exemplify the various discourses currently surrounding transactional sex in PNG today. How is the category of those who sell sex constituted through these discourses, how is it gendered, what provokes and legitimises such extreme violence?

\section{Discourses combining and competing}

\section{Morality and the law}

The formal legal system of PNG is based on English law, introduced to the two colonial territories by way of Australia. This produced a formal legal system which made a small number of piecemeal adjustments to local conditions while maintaining an overall framework of a 'sophisticated, imposed law of the white settler and administrator' (Brown 1969: 10). Practising lawyers and judges were recruited from overseas, principally Australia. Training of Papua New Guinean lawyers did not commence until shortly before Independence. After Independence, the legal system was continued largely unaltered, with its stylised procedures and reliance on written precedent derived initially from the metropole, and while it is poorly understood by non-lawyers, it impinges increasingly on daily life in PNG as society modernises.

In matters of family and sexual relationships, the introduced legal system derives its principles from medieval ecclesiastical law. Legal and Christian moralities reinforce each other, and although in the West the law has been reformed in the last half-century in the light of human rights principles, in PNG this moralistic stance is strongly maintained by Pentecostal, evangelical and charismatic preaching.

\section{The media and the middle class}

The newspaper reports provide the most immediate documentation of the raid and until very recently, with the advent of digital media such as blogging and Facebook, the principal illustration of popular opinion on national issues. The target audience has changed somewhat over the decades. Newspapers in PNG were originally produced by and for the colonists and about the colonised. But by 1985, when Colin Filer published a study of public opinion on bride price through a survey of letters to the newspaper in 1979-80, he noted a citizen readership (and letter writership) which was 'fairly distinctive', in that it was educated and concerned with national issues, but represented only a small proportion of the total population; and which self-identified variously as elites or grassroots, but usually displayed dominant themes of populism while 
siding with capitalism (Filer 1985: 164-65). Twenty years later, Hank Nelson noted the same demographic, of educated, urbanised middle-class Papua New Guineans, including a significant proportion of women, who took an interest in national issues (Nelson 2005: 3,10). Nevertheless, their lifestyles have a significant impact on the rural majority, not least in respect of sexuality and modernisation (Jenkins 2007: 30-31). In contrast to the arcane terminology, complex procedures, alien concepts and general air of mystique of the law, the media discourse is readily available to modern PNG society, both urban and rural, elites and grassroots. Readers both inform and are informed by populist reportage, and it is accorded a high degree of veracity. So errors in reporting, even if they are only grammatical, can be significant.

The National's report of the raid included a purported statement by the Superintendent that the Three-Mile Guesthouse was operating illegally because it did not have a 'proper licence to operate the brothel' - in fact there is no such thing as a brothel licence in PNG. The illegality referred to was that the establishment had no liquor licence. The Post-Courier reported that 'male prostitutes' involved in the raid were freed because there was no law under which to prosecute them (Yiprukaman 2004b), but this was wrong on two counts. First, as to fact: the men involved in the raid were clients, guesthouse staff, bar patrons, even band members, but they were not male sex workers (Hershey 2004: 1). Second, as to the law: as was pointed out to the reporter at the time, Section 55 of the Summary Offences Act does in fact allow the prosecution of any person who lives on the earnings of prostitution, ${ }^{5}$ which would include men (Gerawa 2004). Through a unique and surprising judicial interpretation of the Law Reform Commission's attempt in 1975 to decriminalise prostitution, the gender-neutral language of the Summary Offences Act has been taken to mean that those earning money from selling sex are criminalised along with those originally intended to be the target of the offence, the pimps and madams (see Stewart 2011 for a detailed history). But when several prominent figures were invited to comment on the erroneous assumption of gender bias, the law itself was not questioned or their doubt was not reported.

\section{Global HIV}

Over the last quarter century, the HIV epidemic has produced a number of specialised discourses which have been promulgated, if not necessarily accepted, world-wide. In PNG, the HIV discourse has been most prominently fashioned by international organisations and their templates for the programs and solutions supported by overseas aid, whether for government or civil society: the 'ABC' (Abstinence, Be faithful, use a Condom) prevention strategy; the focus on 'high-

5 The reference to 'Section 55 of the Summary Offences Act of the Criminal Code' is incorrect. 
risk groups' (later altered to 'high-risk settings'); the plethora of acronyms designed to avoid stigmatisation but allegedly increasingly it, such as FSW (female sex workers), MSM (males who have sex with males), VCT (voluntary counselling and testing); and human rights espoused as a basis for policy. This international discourse has been 'localised' through a range of 'cultural and moralistic lenses' (Lepani 2010: 306) and promulgated by the media to its urban readers.

In general, contributors to the Pacific AIDSTOK list, where notice of the raid was first posted on 17 March, upheld the terms of this globalised HIV discourse, though they may on occasion be wary of its wholesale adoption into the Pacific region. They were also willing to espouse elements of both the human rights discourse and the localised cultural discourse.

\section{Human rights-hopefully}

However, the international human rights discourse sits uneasily with other popular discourses in PNG. The law does support the principles of universal human rights: the Constitution guarantees equal treatment of the sexes (Section 55) and prohibits 'treatment or punishment that is cruel or otherwise inhuman' (Section 36). However, although the Constitution is theoretically the supreme law, not all laws are yet fully consistent with it, due to their having been continued from pre-Independence laws and not yet fully revised or properly tested in the courts.

The National's Editorial of 23 March castigated the Central and NCD Police Commander for his dismissive comment that the police 'might have got a bit out of hand' during the raid:

No, Commander Wagambie-your men did not get a bit out of hand.

They disgraced the uniform they wear, and once again brought the reputation of the RPNG Constabulary ${ }^{6}$ tumbling down ... it is impossible to avoid the impression that these policemen took a special delight in inflicting humiliation upon these women and men.

This is the kind of macho image beloved of bullies the world over - the inflicting of shame and disgrace upon people who are utterly helpless.... The fact is that the law is there to protect citizens ... the police are not there to make moral judgements and enforce humiliating and completely

6 Royal Papua New Guinea Constabulary. 
illegal punishment upon a group of unfortunate women ... [who] are also citizens, with access to the full rights accorded to each and every one of us (Editorial (2004b).

The rights discourse was also adverted to in the comments of Dame Carol Kidu and the various NGOs who were present at the police station, notably the Poro Sapot Project and the Individual and Community Rights Forum (ICRAF). It prompted the Human Rights Watch investigation and reports (Human Rights Watch 2005, 2006). And, as noted above, it featured in the AIDSTOK comments on the raid.

But it does not predominate in the urban cultural setting of PNG. Those who witnessed the forced march to the police station, who jeered, pelted the marchers with stones and spat upon them, who accused them of being 'AIDS carriers', were evincing a more visceral reaction than that of an infringement of the fragile concept of human rights. Rather, they were viewing the events unfolding before them through a localised cultural lens which prompted them to condemn the selling of sex and vent their fears about the spread of HIV.

\section{Discourse, opinion and action}

\section{Naming the profession}

Transactional sex flourishes in Port Moresby as in the rest of PNG due to a combination of many factors. These include the effects of the deteriorating economy, which pushes many girls into offering, or being offered for, paid sex to support themselves and their families (Levantis 2000: 67, 69) and the commoditisation of the bride-price system which impels many women to elect to use the money they earn from their bodies for themselves rather than their kin (Jenkins 2007: 13; see also Wardlow 2006; and Kelly et al. 2011). It may also be provoked by resentment at kin for failure to support them over crucial issues (Wardlow 2002); and, as I learned from interviews recorded in 2007, fragile domestic situations which see many women fleeing or being ejected from intolerable and often violent marriages. The conduct of these sexual encounters takes many forms, ranging from street work out-of-doors in bushes, long grass and on the footpaths of commercial districts after hours; through the many nightclubs, guest houses and discos which serve as sexual networking venues; to the marketing of daughters, nieces, even wives, around city offices and 
rural economic enclaves. The relationships involved are not necessarily single encounters - some may be relatively long in duration (Wardlow 2004: 1025; and Kelly 2011). ${ }^{7}$

The range of situations involving monetised sexual exchanges worldwide, and the names and meanings for these transactions and those involved in them, vary enormously (Patton 2002: 89). This makes problematic the use of the terminology, categories, implications and understandings of global discourses (Wardlow 2004). The global HIV discourse has lumped all such exchanges together in the one conceptual category, which is capable of being named and then delineated and described by the names: 'prostitution', 'sex work', 'transactional sex'. The meanings of the names are fashioned by the discourses in which they are embedded, and lend themselves to interpretation in different ways by different social groups (Perkins 1991: 7; Stewart 2011).

The media reports of the raid used the terms 'prostitute' and 'sex worker' interchangeably and sometimes together in the same story, although in later weeks, in describing the various court proceedings which ensued, 'prostitute' and 'prostitution' tended to take precedence. A different set of names was used by those who gathered to witness the forced march to the police station: pamuk meri (TP: loose woman); ${ }^{8}$ AIDS carriers, sik pulap (TP: full of disease); spread sik AIDS (TP: spreaders of the AIDS disease); painim man o (TP: man-chasers); raunraun meri (TP: gadabout woman). Some said 'salim samting blong yupela tumas yupela save pilim pen tu o nogat' (TP: you sell your 'things' so much I guess it doesn't even hurt you).

The term 'prostitute' and its variants are derived from the language of the law. The Colonial Police Offences Ordinances made use of the term, referring to 'the purpose of prostitution' (both Territories) and a 'common prostitute who solicits, importunes or accosts' (New Guinea only) - this despite the fact that the terms are nowhere defined, and some of England's finest legal minds have proved incapable of providing an acceptable definition (Self 2003: 25, 30, 99, 121). Prostitution-related offences were maintained in colonial times, probably in response to concerns from the early twentieth century about dwindling populations and the spread of venereal diseases (Jenkins 2007: 27) and more recently on moralistic grounds - see, for example, the plethora of reports and Letters to the Editor in both daily newspapers of October and November 2010, following Dame Carol Kidu MP's announcement that Cabinet had approved her submission to have the laws regarding prostitution and homosexuality referred for review to the Constitutional and Law Reform Commission.

7 For a more exhaustive overview of the selling of sex in urban and rural PNG, see Jenkins 2006: 34-41.

8 Pamuk is derived from the Samoan paumutu (slang. paumuku) meaning a loose woman, and was probably introduced to PNG by returning plantation labourers (pers. comm. Penelope Schoeffel, 27 February 2005). 
The recent alternative term 'sex worker' is derived from the sexual radicalism of the 1980s and the sex worker movement in the West which viewed prostitution as a form of work and sought to shift the discourse from one of morality to one emphasising economic necessity, and was officially adopted by the global HIV discourse in 1992. It was actively introduced into PNG as part of the global effort in HIV epidemic management which constructed 'high-risk groups' and then 'high-risk settings' as requiring particular attention, and thus needed to describe their members (Patton 2002: 87-89).

However, this process of naming overlooks the fact that neither 'prostitute' nor 'sex worker' is a chosen identity. This is demonstrated by the statements of the women themselves, explaining their presence at the Three-Mile Guesthouse at the time of the raid:

I am resident ... of the premises so I was selling food stuff inside the area (woman, 33).

I was marketing buai [betel nut] and smoke outside of the guesthouse gate.... I brought my son to the laundry and was showering him (woman, 34).

I was employed as a cleaner with Guest house at 3-mile since years now.... I was inside the guest house washing floor (woman, 21).

I was at the 3 Mile Guest house with the group that was playing cards at the back of the guest house (woman, 22).

I went there because I heard that a band was playing (woman, 26).

She is only there waiting for her cousin brothers (band members) to finish play and go home (woman, 38).

I went to the guest house to check for my husband.... I am married with a small girl aged 2 years old (woman, 21).

Whilst on my way [to visit my aunty who lives nearby] I heard life [sic] band was entertaining the people ... so I decided to pip [sic] through the gate (woman, 18).

A band was playing in the guesthouse so myself and a girlfriend went in the premises and sat down watching the band (girl, 17).

These statements were all made for a specific purpose: as evidence in a proposed court case for damages. They were taken down by National AIDS Council officers and sub-committee members, who expressly warned them not to admit to selling sex (although one or two did so nevertheless). The stories are therefore constructed, but this does not necessarily negate the truth of the events they 
recount. Women and girls who sell and exchange sex in Port Moresby (as in the rest of PNG, and the rest of the world) are firstly people. They are daughters, sisters, mothers, girlfriends, wives. They are cleaners, cooks and street vendors. They lead a variety of lives, and are not fundamentally self-defined by the fact that they may sell sex (see McClintock 1993: 1). The terms publicly and 'officially' used for those who engage, however rarely or frequently, in selling or exchanging sex are not universally accepted in PNG. This is true whether it is a term sanctioned by an international aid agency, or hurled as an insult by the crowd which jeered at those in the forced march following the raid. Such terms are all construed as derogatory and based in the same kind of moralistic discourse which produced 'prostitute'.

Women themselves over the years have adopted a variety of localised alternatives. One striking example comes from the 1960s (Johnstone 1993), when an immigrant group from the Highlands termed their women who walked the streets accompanied by their husbands bisnis-meri (TP: businesswomen), a term which predated the western shift of emphasis to the economic nature of the activity and its discourse. Today, women continue to develop their own appellations, often based on some variation denoting 'sister' (Hammar n.d.; see also Hammar 2010). My fieldwork in 2007 revealed the popularity among homeless street-workers in Port Moresby and other towns of the term 'problemmothers', meaning 'mothers with problems'. The fragmented nature of this self-naming indicates the shortcomings of a discourse which seeks to name and thereby categorise people by activities taking place in a range of contexts which may have little in common. This can lead to the conflicts apparent in the epithets hurled at the women as they were marched through the city streets, contrasted with the apparently sympathetic words of the Post-Courier editor who sympathised with those who were obliged to sell sex to 'find money to feed and house themselves' but proceeded to approve the actions of the police commander who warned them of the perils of selling sex while authorising their arrest and detention, in inhumane conditions and in defiance of normal bail procedures (Editorial 2004a, above).

\section{The gendering process}

Cindy Patton points out that the global HIV discourse enabled the conflation of AIDS and selling sex: 'sex workers were largely presumed to be women, and women at risk were assumed to be prostitutes' (Patton 2002: 92). But the gendering of the category of 'prostitute' had already been confirmed in the discourse of colonial law, simultaneously with its naming. References are made in the colonial Ordinances to prostitution by a 'female native' (Native Regulations 1939 (Papua) Section 85), or a 'native woman' (Native Administration Regulations 
1924 (New Guinea) Section 87), or simply, a 'female' (Police Offences Ordinance of New Guinea Section 79); and to male persons living wholly or in part on the earnings of prostitution (Police Offences Ordinance of New Guinea Section 79). Extra emphasis is given to this female gendering by the long-standing rule in PNG's imported legal system that 'words importing the masculine gender include females'. ${ }^{9}$

'On the other hand,' Patton continues, 'men who sell sex to men were lumped together as men who have sex with men' (p. 92). In fact, cases from colonial times had already dealt with situations of males selling sex, mentioning monetary exchange in several. One case file specifically stated that one party to consensual male-male sex was entitled to be exonerated as 'the victim of a male prostitute' (Stewart 2008: 85). However, the criminal charges laid in all such cases are those of sexual acts between males, which carry far higher penalties than the 'prostitution' offences laid against women who sell sex. Hence no public discourse has emerged around the selling or exchanging of sex by men. Rather, in the case of sex between males, attention has focused on the conflation of consensual sex between adults with forced sex and sex with under-aged boys, all of which are lumped together in media reportage as 'sodomy' (see for example Sete 2008; Yadi 2006).

Perhaps, because of this history of avoiding reference to the selling of sex by males, it is not surprising that the comparatively novel concept of 'male prostitutes' caught up in the raid was taken up so eagerly by the media. Over the week following the raid, both newspapers solicited comments from prominent people on this topic. First was the National on Wednesday 17 March, reporting that officials of the NGO Individual and Community Rights Advocacy Forum (ICRAF) explained that the law

covered both male and female prostitutes.... How can the police justify their actions by saying the law only relates to women? Where is the justice that they are supposed to be providing to the people of this land when they clearly have a prejudice against women? (Gerawa 2004).

On the same day, in a horrified letter headed 'Crime to Be a Woman?' a (male) writer complained bitterly about the discrimination evidenced by:

this apparent male chauvinistic ideology which stigmatises the female gender as sexual entrepreneurs. After the motley gang of both male and female sex workers were detained and interrogated, males were vindicated but the females were castigated ... if this case reveals an 
inherent legislative bias that privileges the male gender against moral and legal indictment, it is also a case that points to the dehumanisation of the female species. Is it a crime to be a woman? (Moutu 2004: 10).

The Post-Courier sought comment from the Community Development Minister, now Dame Carol Kidu, who condemned the police brutality and reportedly mentioned that 'the fact that only the women were victimised was unjust because both males and females were arrested during the raid' (Yiprukaman 2004c).

On Friday 19 March, the Minister responsible for the police Mr. Bire Kimisopa described the release of the forty-five male prostitutes as a 'joke' and a 'completely stupid' action by police because not all sex workers were females. 'I want a review on the whole incident and all male suspects to be brought in and charged appropriately,' he said, adding that he would be writing to Police Commissioner Sam Inguba to have the officer responsible charged for releasing the male prostitutes. 'The release of the male prostitutes is a terrible injustice to the female citizens of this country,' Mr. Kimisopa said (Yiprukaman 2004d).

These criticisms resorted to the argument of lack of gender equality, which should have seen 'male prostitutes' locked up as well. Even though men as well as women were treated violently, commentators assumed that the police had acted in freeing the men on the basis of gender rather than deciding whether they were or were not engaged in selling sex. But many of the defenders of gender equality failed to condemn the violence and abuse, and only Dame Carol Kidu queried the criminalisation of sex work. Others seem to have thought it more important to punish the alleged AIDS carriers than to query the justification underlying the law which criminalises all those who live on the earnings of prostitution. It seems that they preferred to ensure that all men who might behave like the outclass of women who sell sex-allegedly the vectors of disease - should be re-gendered so as to deserve equal ill-treatment.

But males who sell sex do not fit into the standard category of the mobile, financially-independent woman deserving of punishment. Violence between men is usually prompted by disputes over property, territory or status - things to which all those gendered as male are entitled. So the appeals to 'fairness' and the constitutional guarantee of equality which, it was claimed, should have seen these men locked up as well, may be seen as an attempt to render them visibleto de-masculinise them and re-gender them as feminised outcasts deserving of punishment similar to that meted out to the women. 


\section{Why the violence?}

ASAONET contributors were particularly interested in the causes of the violence, and discussion centred on this aspect of the raid. ${ }^{10}$ There have been many studies of violence against women in PNG, both in the domestic sphere and beyond. Writers such as Lisette Josephides (1994), Laura Zimmer-Tamakoshi (1997) and various contributors to Sinclair Dinnen and Allison Ley's edited volume (2000) agree that the underlying cause of the steady increase in this violence is men's fear of losing their control over women. Modernity, urbanisation, globalisation all contribute to the greater economic and social freedom of women, particularly those in urban centres. Women, albeit subordinated or downright rebellious beings, are therefore seen to invite deserved violence. It seems those who sell sex, appearing as both economically independent and powerful, and refusing to submit to the ongoing control of any one man or group of men, are particularly threatening to men.

\section{Uncontrollable women}

A frequently repeated popular view of women's status in traditional society is that they were oppressed chattels (King, Lee and Warakai 1985: 3). ${ }^{11}$ In post-independent PNG, women's status has deteriorated even from this earlier inequality (see Macintyre 1998). Ten years after Independence, women were declaring that they had become less, not more, visible - they were discriminated against in politics, economics and education; and violence against women was increasing (Macintyre 1998: 3-4). Modernisation and development placed greater burdens on women in many ways, while men accumulated power and wealth at their expense. Tradition was manipulated and re-invented to justify the suppression of women, while men adapted to the new society with all its opportunities (Mandie 1985: 170).

Bruce Knauft (1997: 233-34, 242-43) notes how the increasing dependence on trade goods, development and wealth has altered but maintained masculine prestige and female propriety. He discusses the classic view that gendered oppositions, resentment of women and male bonding operate to sustain social cohesion in many traditional Melanesian societies, echoing and doubtless drawing upon the western double standard of femininity which constructs

10 Unfortunately, I have not saved this correspondence, but I do recall an initial posting by Deborah Gewertz, followed by comments from Marta Rohatynskyj, Penelope Schoeffel and Dorothy Counts, all of which inspired me to propose the ASAO meeting session from which this volume emerged.

11 However, this has been challenged by Papua New Guinean women themselves, who claim that traditional gender roles were complementary, if not always equal. See Kekedo 1985; King 1985; Mandie 1985; DicksonWaiko 2003. 
women either as virtuous mothers or wanton whores (Booth 1998: 116; Summers 1994). He contends that these oppositions have firmed in the modern PNG context, where

masculine identities are stressed and threatened ... [and] indigenous beliefs concerning sexuality abut newer practices that commoditize sex and enforce a moral divide between marriage and prostitution ... rais[ing] the threat that women could use sexual favours to redirect wealth to themselves ... women of traditional virtue or Christian propriety are increasingly judged not just against standards of female pollution but against those of being a loose woman or prostitute (Knauft 1997: 243).

Hence the compliant, subservient village woman becomes the virtuous urban Christian housewife; the polluting, dangerous woman-rebel translates into the geographically mobile, financially independent, beer-drinking, unmarried or nolonger-married woman who is easily labelled as loose or pamuk (TP) (Clark n.d.: 18; Wardlow 2006). In contemporary PNG, where sex has become commoditised and a moral divide between marriage and prostitution has firmed, it is an easy step to perceiving the latter as 'prostitutes' (Jolly 2001: 198).

\section{HIV: Pollution and disease}

The raid in 1998 was the first to be claimed publicly as having been motivated by HIV-related concerns:

Supt. Gawi said apart from curbing suspected brothels, the police effort should be seen as an attempt to eliminate the spread of AIDS and other sexually transmitted diseases (Terry 1998: 3).

By 2004, however, HIV prevention was claimed as the prime motivation for the Three-Mile Guesthouse raid, as evidenced not only by the address of the Police Metropolitan Superintendent but also by the way in which condoms featured strongly in the abuse of the women. ${ }^{12}$

It is commonplace to attribute the threat of disease to women. Mary Douglas, in her classic study of pollution and taboo (1966), suggested that pollution beliefs are a way of imposing control on such chaotic phenomena as illness and desire, which threaten social boundaries. These boundaries are particularly porous in sexual relations, which transgress the body's boundaries and involve class and status struggles. In PNG, traditional beliefs relating to the potential dangers to men of sex and other contact with women, particularly with menstrual blood, are widespread (see for example Clark n.d.: 191; Langness 1999: 170; Wardlow

12 The advocating of condoms for HIV prevention is a highly controversial issue in PNG: it has even been suggested recently that the State should be liable in damages for their promotion (Nyan 2006). 
2006: 54-56). ${ }^{13}$ Current fears of HIV infection through sexual contact cohere with these pollution beliefs, as well as meshing with the general attribution of pollution and disease to women.

The perceived threat posed by women increases exponentially when the woman sells sex. The view of such women as vectors of disease and infection has been well-documented in the metropoles. Maggie $\mathrm{O}^{\prime}$ Neill describes the situation in nineteenth-century France, where one of the main concerns regarding the regulation of prostitution was the fact that its practitioners were seen as diseased (1997: 5-6). In England, concerns about the spread of venereal disease in military garrisons led to the enactment of the Contagious Diseases Acts in the 1860s (Walkowitz 1982: 1; Chancer 1993: 145) and these concerns were often exported to the colonies (Howell 2004; Phillips 2002, 2005; for PNG, Reed 1997; Lepani 2008, 2012; and for Australia, see Perkins 1991: 73-74). 'Prostitutes' were condemned for carrying disease while at the same time the local sex industry was structured by regulation and policy to cater for single men, ${ }^{14}$ a theme often repeated in the developing world, both during and after the colonial era (Phillips 2002: 343; Stoler 2003: 48; Sandy 2007: 201, 235-38).

This view of those selling sex as vectors of disease and infection was imported into PNG by way of the Anglo-Australian colonisation process, both through metropolitan laws and policy and through mission preaching. Today, the HIV discourse classifies the promiscuous purveyor of sex as one who has 'flouted the norms of monogamous heterosexuality (and mainstream public health)' (Hammar 2008: 60), and hence is considered a member of a 'high-risk group', or more recently, as conducting 'risk activities' in a 'high-risk setting'. It is a further easy step to link this woman with the dangerous polluter of traditional culture, as shown by the abusive names used to humiliate the marching women. The assault with the air freshener canister was more than rape-it was the symbolic destruction of a source of pollution.

\section{Conclusions}

Commentators on the Three-Mile Guesthouse Raid have had recourse to various social discourses in their reportage. These discourses have combined to direct opinion and ultimately action in specific, socially approved directions. Chief among them are the discourse of the media, which represents and informs urbanised opinion, both middle-class and grassroots; the discourse of the

13 Such beliefs are not unique to PNG. See for example Mary Douglas 1966.

14 The irony is that impartial studies which favour investigation over judgement show that the reverse is often the case: sex workers are aware that they are more endangered, and are more likely to develop strategies to safeguard their health (Chancer 1993: 149-50). 
introduced legal system allied with Christian morality; the HIV discourse, founded internationally and modified locally; the discourse of traditional 'culture'; the discourse of local popular culture which saw the ready use by spectators to the forced march of abusive and insulting language; and the human rights discourse, also founded internationally but often locally in conflict with these and other discourses.

The law and the media in PNG have combined to create a female-gendered category of 'prostitute'. This category has been set apart from the 'normal' idealisation of the modern PNG woman, who is even more in need of control and containment, lest she acquire education, employment, financial independence and mobility, which are those same scarce prestigious things sought by men (Jolly 2001: 193-94). Most of all, women should observe sexual proprieties, and those who do not - who are mobile, immodest or promiscuous - are 'asking for' condemnation and punishment. This view is lent support by the HIV discourse which constructs and focuses attention on 'high-risk' groups. By persisting in criminalising the selling of sex through the charge of 'living on the earnings of prostitution', the law has facilitated an expanding culture of violence inflicted on those women classed as engaging in commercial sex. The violence may be regarded as a form of punishment for transgressing social norms and thereby allegedly threatening society.

The human rights discourse seeks such lofty ideals as equality and freedom from abuse. But it is the weakest link in the chain of combined discourses, and when it is at odds with them, it generally loses out or is qualified. Equality of the sexes is an argument employed by those wishing to prove themselves both modern and knowing. But equal treatment for all before the law and the right to state protection against gender violence - these still take second place when the groups claiming these rights feel themselves threatened from within. This is a 'borderland' which is still highly contested, where legal/moral debates still prevail (see Merry 2001, 2006). Does gender equality entail that there should be equally abusive treatment meted out to all those not observing the proprieties and threatening the social body by their becoming 'vectors of infection'? Even the gendering of the prostitute breaks down when males are believed to cast themselves as 'sex workers', as equally social outcasts.

One feature of the reportage stands out. Several commentators, in the name of the constitutional principle of gender equality, chose to criticise the police behaviour not on the grounds of violence which infringed the constitutional right to freedom from cruel or unusual treatment, but on the grounds that the men who were (erroneously) presumed to be 'sex workers' were given an unfair advantage over their female counterparts. They were freed, and this breached the right of equality. It seems that, rather than complaining about the unfair 
violence, or the unfair law which led to it, some preferred to ensure that all males who might behave similarly to the outclass of 'prostitutes' should be regendered so as to deserve equal ill-treatment.

Andrew Moutu might well ask: Is it a crime to be a woman? The answer is: yes, when the woman belongs to a category of society without rights, the sexual entrepreneur gendered female, feared and outcast. And, it seems, that in a twisted application of notions of gender equality, males who behave like femalegendered prostitutes are equally culpable.

\section{References}

Booth, Karen M., 1998. National mother, global whore, and transnational femocrats: the politics of AIDS and the construction of women at the World Health Organization. Feminist Studies 24: 115-39.

Brown, Bernard John, 1969. Fashion of Law in New Guinea: Being an Account of the Past, Present and Developing System of Laws in Papua and New Guinea. Sydney: Butterworths.

Chancer, Lynn Sharon, 1993. Prostitution, feminist theory, and ambivalence: notes from the sociological underground. Social Text 37: 143-71.

Clark, Jeffrey, n.d., Huli Sexuality, the State, and STD/AIDS Prevention Programmes. Goroka, PNG: PNG Institute of Medical Research.

Dickson-Waiko, Anne, 2003. The missing rib: mobilizing church women for change in Papua New Guinea. Oceania 74(1-2): 98-119.

Dinnen, Sinclair, 1998a. Criminal justice reform in Papua New Guinea. In Governance and Reform in the South Pacific, ed. Peter Larmour, 253-72. National Centre for Development Studies. Canberra: The Australian National University.

1998b. Law, order, and state. In Modern Papua New Guinea, ed. Laura Zimmer-Tamakoshi, 333-50. Kirksville, Missouri: Thomas Jefferson University Press.

2001. Law and Order in a Weak State: Crime and Politics in Papua New Guinea, Honolulu: University of Hawai'i Press and Adelaide: Crawford House Publishing.

Douglas, Mary, 1966. Purity and Danger: An Analysis of the Concepts of Pollution and Taboo, Routledge and Kegan Paul, London. 
Editorial, 2004a. Give thought to rehabilitation. Post-Courier. Port Moresby, PNG (15 March): 10.

------- 2004b. A sad new chapter in police arrogance. National. Port Moresby, PNG (23 March).

Filer, Colin, 1985. What is this thing called 'brideprice'? Mankind 15: 163-83.

Gerawa, Maureen, 2004. Police wrong: NGO. Post-Courier. Port Moresby, PNG (March 17): 4.

Global Network of Sexwork Projects, 2011. nswp Global Network of Sexwork Projects: Promoting Health and Human Rights. Online: http://www.nswp. org. Accessed 5 April 2011.

Goddard, Michael, 2001. From rolling thunder to reggae: imagining squatter settlements in Papua New Guinea. Contemporary Pacific 13: 1-32.

2005. The Unseen City: Anthropological Perspectives on Port Moresby, Papua New Guinea. Canberra: Pandanus Press.

Hammar, Lawrence, n.d. The 's' words: 'sex', 'sex worker', and 'stigma' in Papua New Guinea. Papua New Guinea Institute of Medical Research. Ms in author's collection.

2008. Fear and loathing in Papua New Guinea: sexual health in a nation under siege. In Making Sense of AIDS: Culture, Sexuality, and Power in Melanesia, ed. Leslie Butt and Richard Eves, 60-79. Honolulu: University of Hawai'i Press.

------ 2010. Sin, Sex and Stigma: A Pacific Response to HIV and AIDS. Wantage, UK: Sean Kingston Publishing.

Hershey, Christopher, 2004. Statement of facts on police raid at 3-Mile Guesthouse 12 March 2004 and related incidents. Statement made on behalf of Poro Sapot Project, Save the Children in Papua New Guinea (20 March).

Howell, Philip, 2004. Sexuality, sovereignty and space: law, government and the geography of prostitution in colonial Gibraltar. Social History 29: 445-64.

Human Rights Watch (Coursen-Neff, Zama), 2005. Making their own rules: police beatings, rape and torture of children in Papua New Guinea. Human Rights Watch (30 August). Online: http://www.hrw.org/en/reports/2005/08/30/ making-their-own-rules-0. Accessed 7 February 2011. 
2006. 'Still making their own rules': ongoing impunity for police beatings, rape, and torture in Papua New Guinea. Human Rights Watch. Online: http://www.hrw.org/en/reports/2006/10/29/still-making-their-ownrules-0. Accessed 7 April 2011.

Human Rights Watch, 2011. Human Rights Watch. Online: http://www.hrw. org. Accessed 5 April 2011.

Jenkins, Carol, 2000. Female Sex Worker HIV Prevention Projects: Lessons Learned from Papua New Guinea, India and Bangladesh. Geneva: Joint United Nations Programme on AIDS (UNAIDS).

2007. HIV/AIDS, culture, and sexuality in Papua New Guinea. In Cultures and Contexts Matter Understanding and Preventing HIV in the Pacific, ed. Carol Jenkins and Holly Buchanan-Aruwafu. Asian Development Bank. Online: http://www.adb.org/Documents/Books/Cultures-Contexts-Matter/ HIV-PNG.pdf. Accessed 7 April 2011.

Johnstone, Joan D., 1993. The Gumini Bisnis-Meri: a study of the development of an innovative indigenous entrepreneurial activity in Port Moresby in the early 1970s. PhD thesis. Brisbane: University of Queensland.

Jolly, Margaret, 2001. Damming the rivers of milk? Fertility, sexuality, and modernity in Melanesia and Amazonia. In Gender in Amazonia and Melanesia: An Exploration of the Comparative Method, ed. Thomas Gregor and Donald Tuzin, 175-206. Berkeley: University of California Press.

Josephides, Lisette, 1994. Gendered violence in a changing society: the case of urban Papua New Guinea. Journal de la Société des Océanistes 99: 187-96.

Kekedo, Jean, 1985. Equality and participation in Melanesia. In From Rhetoric to Reality? Papua New Guinea's Eight Point Plan and National Goals after a Decade, ed. Peter King, Wendy Lee and Vincent Warakai, 350-55. Waigani, Papua New Guinea: University of Papua New Guinea Press.

Kelly, Angela et al., 2011. Askim na Save (Ask and Understand): People who Sell and/or Exchange Sex in Port Moresby. Papua New Guinea Institute of Medical Research and the University of New South Wales, Sydney, Australia.

King, Peter, Wendy Lee and Vincent Warakai, 1985. From Rhetoric to Reality? Papua New Guinea's Eight Point Plan and National Goals after a Decade. Waigani, Papua New Guinea: University of Papua New Guinea Press.

Knauft, Bruce M., 1997. Gender identity, political economy and modernity in Melanesia and Amazonia. Journal of the Royal Anthropological Institute 3: 233-59. 
Konia, Ruth, 1998. 20 women held in police raid. National, Port Moresby, PNG (December 17): 1-2.

Langness, Lewis L., 1999. Men and 'Woman' in New Guinea. Novato, California: Chandler \& Sharp, Publishers Inc.

Law Reform Commission of Papua New Guinea, 1975. Report No.1: Report on Summary Offences. Waigani, Papua New Guinea: Law Reform Commission of Papua New Guinea.

Lepani, Katherine, 2008. In the process of knowing: Making sense of HIV and AIDS in the Trobriand Islands of Papua New Guinea. PhD thesis Anthropology. Canberra: The Australian National University.

2010. 'Steady with custom': mediating HIV prevention in the Trobriand Islands, Papua New Guinea. In Plagues and Epidemics: Infected Spaces Past and Present, ed. D. Ann Herring and Alan C. Swedlund, 305-22. WennerGren Foundation Monograph Series. Oxford: Berg Publishers.

2012. Islands of Love, Islands of Risk: Culture and HIV in the Trobriands. Nashville, TN. Vanderbilt University Press.

Levantis, Theodore, 2000. Papua New Guinea: Employment, Wages and Economic Development. Canberra: Asia Pacific Press.

Mandie, Angela, 1985. Institutional and ideological control of gender in a transitional society. In From Rhetoric to Reality? Papua New Guinea's Eight Point Plan and National Goals after a Decade, ed. Peter King, Wendy Lee and Vincent Warakai, 166-71. Waigani, Papua New Guinea: University of Papua New Guinea Press.

McClintock, Anne, 1993. Sex workers and sex work: introduction. Social Text 11: $1-10$.

Merry, Sally Engle, 2001. Changing rights, changing culture. In Culture and Rights: Anthropological Perspectives, ed. Jane K. Cowan, Marie-Bénédicte Dembour and Richard A. Wilson, 31-55. Cambridge: Cambridge University Press.

2006. Transnational human rights and local activism: mapping the middle. American Anthropologist 108(1): 38-51.

More mothers, students HIV positive in Morobe, 2008. In Post-Courier. Port Moresby, PNG, 6 June. Online: http://www.postcourier.com.pg/20080606/ frhome.htm. Accessed 21 January 2011. 
Moutu, Andrew, 2004. Crime to be a woman? Letters to the Editor. Post-Courier, Port Moresby, PNG (March 17): 10.

National AIDS Council Secretariat, 2004. Legal Briefing: Police Raid on ThreeMile Guest House. Port Moresby: National AIDS Council Secretariat.

Nelson, Hank, 2003. Dear Sir...: Evidence of civil society in the media of Papua New Guinea. Paper given at USP/ANU/FDC Suva Symposium, Suva, Fiji.

Nicholas, Isaac, 1996. Forty held in capital city brothel raid. Post-Courier. Port Moresby, PNG, (25-27 October): 1-2.

Nyan, Avisat, 2006. Reconsider condom policy. National. Port Moresby (7 December).

Ombudsman Commission of Papua New Guinea, 2009. Investigation report into the alleged unlawful and abuse of human rights by police, Three Mile Guest House, Port Moresby. Port Moresby, PNG: National Capital District, National Parliament.

O'Neill, Maggie, 1997. Prostitute women now. In Rethinking Prostitution: Purchasing Sex in the 1990s, ed. Graham Scambler and Annette Scambler, 4-28. London and New York: Routledge.

Patton, Cindy, 2002. Globalising AIDS. Minneapolis and London: University of Minnesota Press.

Perkins, Roberta, 1991. Working Girls: Prostitutes, their Life and Social Control. Canberra: Australian Institute of Criminology.

Phillips, Richard, 2002. Imperialism and the regulation of sexuality: colonial legislation on contagious diseases and ages of consent. Journal of Historical Geography 28: 339-62.

2005. Heterogeneous imperialism and the regulation of sexuality in British West Africa. Journal of the History of Sexuality 14: 291-362.

Pilimbo, Peku, 2004. Police arrest 80 in brothel raid. National. Port Moresby (15 March): 5.

Reid, Elizabeth, 2010. Putting values into practice in PNG: the Poro Sapot Project and aid effectiveness. In PacifiCurrents, issues 1.2 and 2.1, (April), online: http://intersections.anu.edu.au/pacificurrents/reid.htm. Accessed 15 December 2010. 
Sandy, Larissa, 2007. 'My blood, sweat and tears': female sex workers in Cambodia-victims, vectors or agents? PhD thesis. Canberra: Australian National University.

Secretariat of the Pacific Community, 2011. SPC Secretariat of the Pacific Community. Online: http:// www.spc.int/. Accessed 5 April 2011.

Sela, Robyn, 1998. Midday raid of house sees 25 behind bars. Post-Courier. Port Moresby, PNG (17 December): 3.

Self, Helen J., 2003. Prostitution, Women and Misuse of the Law. London and Portland OR: Frank Cass Publishers

Sete, Annette, 2008. Sodomist gets 21 year jail term. Post-Courier. Port Moresby, PNG (20 May): 6.

Stewart, Christine, 2008. Men behaving badly: sodomy cases in the colonial courts of Papua New Guinea. The Journal of Pacific History 43: 77-93.

2011. Pamuk na Poofta: criminalising consensual sex in Papua New Guinea. PhD thesis. Canberra: The Australian National University.

Stoler, Anne Laura, 2003. Carnal Knowledge and Imperial Power: Race and the Intimate in Colonial Rule. Berkeley: University of California Press.

Summers, Anne 1994. Damned Whores and God's Police. Ringwood, Vic.: Penguin.

Terry, David, 1998. Police parade suspects in the streets. Post-Courier. Port Moresby, PNG (17 December): 3.

Walkowitz, Judith R., 1982. Prostitution and Victorian Society: Women, Class, and the State. Cambridge England and New York, NY: Cambridge University Press.

Wardlow, Holly, 2002. Passenger-women: changing gender relations in the Tari Basin. Papua New Guinea Medical Journal 45(1-2): 142-46.

2004. Anger, economy and female agency: problematizing 'prostitution' and 'sex work' among the Huli of Papua New Guinea. Signs 29(4): 1017-39.

2006. Wayward Women: Sexuality and Agency in a New Guinea Society. Berkeley and Los Angeles: University of California Press.

Yadi, Abby. 2006. Sodomy Shock. Post-Courier, 21 January.

Yiprukaman, Michelle, 2004a. Sex workers 'on parade'. Post-Courier. Port Moresby, PNG (15 March): 1 . 
2004b. Males 'freed' ... but 31 suspected female prostitutes charged! Post-Courier. Port Moresby, PNG (16 March): 1 .

2004c. Kidu: probe raid on city brothel. Post-Courier. Post Moresby, PNG (18 March): 4.

2004d. Police actions damned. Post-Courier. Port Moresby, PNG (19 March): 4.

Zimmer-Tamakoshi, Laura, 1997. 'Wild pigs and dog men': rape and domestic violence as 'women's issues' in Papua New Guinea. In Gender in CrossCultural Perspective, ed. Caroline B. Brettell and Carolyn F. Sargent, 538-53. Upper Saddle River, NJ: Prentice Hall. 